\title{
公的賃貸集合住宅団地の再生における駐車場設置指導の課題 ISSUES OF PARKING INSTALLATION GUIDANCE IN THE REDEVELOPMENT OF PUBLIC RENTAL HOUSING COMPLEX
}

\author{
保 持尚志*, 片岡由香**, 倉知 徹***, 江川直 樹**** \\ Takashi YASUMOCHI, Yuka KATAOKA, Tohru KURACHI \\ and Naoki EGAWA
}

\begin{abstract}
In this study, the following was revealed on the public rental housing complex (PRHC) in Osaka Prefecture. 1.The number of the PRHC that doesn't meet the criteria installation rate of parking, 2.The number of the PRHC with a surplus in the parking lot, 3.Guidance situation of municipalities in the redevelopment. As a result, 87.3\% of the PRHC that were built in 1965-1974 doesn't meet the installation criteria, and in addition, there is a surplus of parking lot on $90.0 \%$ of them. When the municipality applied the criteria of the current situation to redevelopment of the PRHC that doesn't meet the criteria despite the surplus of parking lot, the wasted space would be generated. Therefore the current parking installation criteria must be revised by placing the guidance for the redevelopment, to not generate a useless space.
\end{abstract}

Keywords: Public rental housing complex, Parking lot, Development guidelines, Installation criteria 公的賃貸集合住宅団地, 駐車場, 開発指導, 設置基準

1.はじめに

\section{1 研究の背景と目的}

公的賃貸集合住宅団地（以下団地）において、既設の駐車場台数が、 市町村の条例や開発指導要綱等に示される設置基準 (共同住宅の開 発時に設置しなければならない駐車場台数）を満たしていない団地 がある。しかし近年、駐車場台数が設置基準より少ないにも係わらず、 駐車場を部分的に閉鎖するなど、駐車場台数に余剩のある団地がみ られる。

一方で、一部の団地では、住棟、設備の老朽化などの物理的問題、 高齢化率の上昇、空き家の増加、コミュニティの衰退などの社会的 問題が顕在化しており、特に今後、築 50 年を迎える昭和 40 年代 $(1965$ 〜 1974 年) に建設された団地において、建替えや増改築、コンバー ジョンなどの再生、高齢者の生活支援、若年層の入居促進、コミュ ニティ活動の支援などの新たな機能、施設導入の必要性が高まると 考えられる。

駐車場台数に余剩がある団地が、設置基準を満していない場合、 市町村の駐車場設置指導に沿って設置基準を満たす再生が行われる と、余剩があるにもかかわらず駐車場が増設され、余剩がさらに増 加する。居住世帯の入替わりに伴う自家用車保有状況の変化を吸収 する分を超える余剩は、(1)駐車場以外の共用空間を減少させ、住空 間の質を損ない、さらに新たな機能、施設導入を困難にする、(2)バ
リゲード等で閉鎖した場合に、団地の活況感を損ない、住宅地景観 を悪化させる、(3)維持費が高額な機械式駐車場とした場合には、維 持管理が困難になるといった問題の原因となる。

団地の再生では、駐車場は余剩が生じないよう必要な分を整備し、 居住世帯の生活を支える施設を導入するなど、空間を有効に利活用 することが望ましい。

本研究は、(1)駐車場の設置率 (= 駐車場設置台数 / 管理戸数) が市 町村の設置基準を満たしていない団地数、(2)それらの団地のうち駐 車場台数に余剩のある団地数、(3)団地の再生に対寸る駐車場設置指 導の対応状況を明らかにし、(4)団地の再生における駐車場設置指導 の課題とあり方について示すことを目的とする。

\section{2 研究の方法}

大阪府営住宅 (以下府営住宅)、大阪府住宅供給公社の貨貸集合 住宅 (以下公社団地)、大阪府にあるUR 都市再生機構の賃貸集合 住宅（以下UR団地）のうち、管理戸数 200 戸以上の団地を対象に 注 1)、(1)設置率が設置基準を満たしていない団地数を明らかにするこ とを目的として、団地の管理戸数と駐車場設置台数、それぞれの団 地がある市町村の設置基準を調查し、設置率と設置基準を比較した。 (2)駐車場台数に余剩のある団地数を明らかにすることを目的として、 団地の駐車場契約台数と居住戸数を調查し、駐車場契約台数を保有

\footnotetext{
* 関西大学大学院理工学研究科 博士後期課程

** 愛媛大学防災情報研究センター 助教・博士 (工学)

*** 関西大学先端科学技術推進機構 特任研究員 · 博士 (工学)

**** 関西大学 教授. 修士 (工学)
}

Doctoral Course Graduate School of Engineering Kansai University

Research associate, Center for Disaster Management informatics Research, Ehime University, Dr.Eng.

Research Fellow, Kansai University, Dr.Eng.

Prof., Kansai University, M.Eng. 
台数と見なし、自家用車の保有率 (=保有台数 / 居住戸数) を求め、 設置率を比較した。

一方で、(3)団地の再生に対する駐車場設置指導の対応状況を明ら かにすることを目的として、大阪府下の市町村を対象にアンケート 調查を行った。

これらの結果を踏まえ、(4)団地の再生における駐車場設置指導の 課題とあり方を考察した。

本論では、駐車場台数の余剰を以下の通り定義した。

それぞれの団地において、居住世帯の自家用車保有状況から、設 置が必要とされる駐車場台数 (必要駐車場台数) を、「管理戸数 $\times$ 保 有率」によって求められる值とし、設置台数との差、「駐車場設置台 数一必要駐車場台数」を余剩台数とした。そして余剩台数を管理戸 数で除して一般化した值を、需給差（単位：ポイント）とし、設置 台数が必要台数より多く、需給差が正の場合には余剩があり、逆に 少なく、負の場合には余剩がないと定義した。なお、需給差を求め る式を変換すると、設置率と保有率の差、「設置率一保有率」によっ て表され、本論では、需給差を団地の駐車場の余剩を定量的に示す 指標とした。

空き駐車場台数の実数である「駐車場設置台数一保有台数」を余 剩台数としなかったのは、団地に空き住戸がある場合において、空 き駐車場台数の実数には、空き住戸に入居する世帯が必要とする分 の台数が含まれることから、余剩を過大に評価することを避けるた めである。

本論では、居住世帯の自家用車保有に係る属性（保有の有無や台 数）は、団地の立地、交通の利便性などから決定されると考え、空 き住戸に入居する世帯の保有率を、現状の居住世帯の保有率と同率 とし、空き住戸に入居する世帯が保有すると想定される台数を、「空 住戸数 $\times$ 保有率」として求めた。この想定される台数と保有台数を 加えた台数を、必要駐車場台数とし(これは管理戸数×保有率によっ て求められる)、設置台数との差、「設置台数一必要駐車場台数」を 余剩台数とした注 2 )。

なお、需給差が負の場合、余剩がないと定義したが、そのような 団地でも実際の駐車場台数の不足にはならない注 3$) 。$

\section{3 研究の位置づけ}

北原ら ${ }^{1)}$ は 1988 年に仙台市内の公営住宅における駐車場設置状況、 田中 2) は 1989 年に名古屋市営住宅における自家用車保有状況を調査 し、自家用車台数が駐車場台数を大きく上回る状況での駐車場整備 の課題について検討している。関原ら ${ }^{3)}$ は 1991 年において、新築の UR 賃貸住宅では保有率を概ね充足する設置率が確保される状況にあ るが、さらに高設置率化に向けた課題があると述べている。これらは、 駐車場の増設が強く求められた社会状況における課題を述べており、 本研究とは社会状況が異なる。

福岡ら ${ }^{4)}$ 、南ら ${ }^{5)}$ は、近年の民間マンションや団地では、駐車場 の占める空間が過大であると指摘し、今後の駐車場空間のあり方を 検討している。これらの研究では、需要を満た寸分の駐車場がある 集合住宅団地における駐車場空間のあり方を検討している。しかし 余剩の駐車場や駐車場設置指導について検討したものではない。

賀満田ら ${ }^{6)}$ は、近年に新築された民間分譲集合住宅における空き駐 車場の状況を示し、設置基準が過大であることを述べている。しか し団地の駐車場、駐車場設置指導について検討したものではない。
本研究は、公的賃貸集合住宅団地に着目し、駐車場台数に余剩の ある団地の状況、駐車場設置指導の状況を明らかにし、団地の再生 における駐車場設置指導の課題とあり方を示した点が、既往の研究 と異なる。

\section{2. 駐車場の設置率が設置基準を満たさない団地数 \\ 2. 1 調査概要}

「駐車場の設置率が設置基準を満たさない団地数」を明らかにする ことを目的として、以下の調查を行った。対象団地における管理戸 数と駐車場設置台数について、各事業者から情報の提供を受け注 4)、 これより設置率を求めた。また大阪府下 43 市町村における設置基準 について、条例や指導要綱等から整理した。これより設置率と設置 基準を比較し、設置率が設置基準を満たしていない団地数を求めた。

情報が提供された 357 団地（府営住宅 194 団地 106, 457 戸、公社 団地 38 団地 13, 266 戸、UR 団地 125 団地 98,445 戸：表 1) を「全対 象団地」として検討した。また 357 団地のうち、昭和 40 年代 $(1965$ 〜 1974 年) に建設された団地は、他の年代と比較して 150 団地（府 営住宅 94 団地 61, 559 戸、公社団地 22 団地 8, 835 戸、UR 団地 34 団 地 46,633 戸) と多く、今後築 50 年を迎え、再生の必要性が高まる と考えられることから、「S40 年代団地」として検討した。

\section{2 調査結果}

\section{(1) 設置率}

\section{1)「全対象団地」（図 1)}

府営住宅における平均の設置率は $57.6 \%$ であった。 $50 \%$ 以上 $75 \%$ 未 満の団地が多かった。公社団地における平均の設置率は $72.4 \%$ で、 府営住宅、UR団地より高く、 $50 \%$ 以上 $75 \%$ 未満、 $75 \%$ 以上 $100 \%$ 未 満の団地が多かった。UR団地における平均の設置率は $49.7 \%$ で、 $25 \%$ 以上 $50 \%$ 未満、 $50 \%$ 以上 $75 \%$ 未満の団地が多かった。

表 1 調査対象団地

\begin{tabular}{|c|c|c|c|c|}
\hline 建設年 & 府営住宅 & 公社団地 & UR団地 & 計 \\
\hline$\sim 1964$ & 16 & 0 & 8 & 24 \\
\hline $1965 \sim 1974$ & 94 & 22 & 34 & 150 \\
\hline $1975 \sim 1984$ & 24 & 5 & 35 & 64 \\
\hline $1985 \sim 1994$ & 25 & 0 & 21 & 46 \\
\hline $1995 \sim 2004$ & 13 & 1 & 21 & 35 \\
\hline $2005 \sim$ & 22 & 10 & 6 & 38 \\
\hline 計 & 194 & 38 & 125 & 357 \\
\hline
\end{tabular}

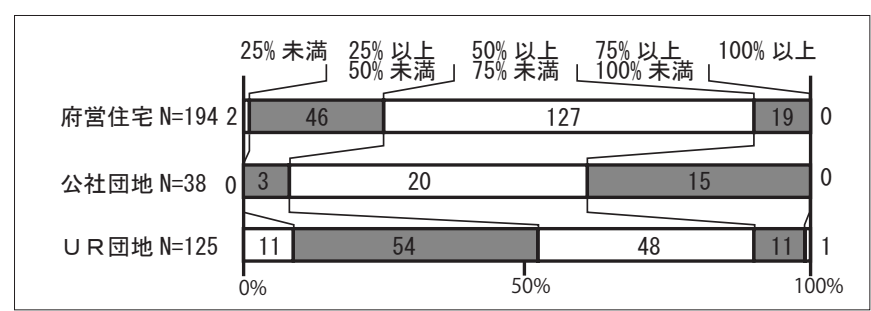

図 1 駐車場設置率（全対象団地）

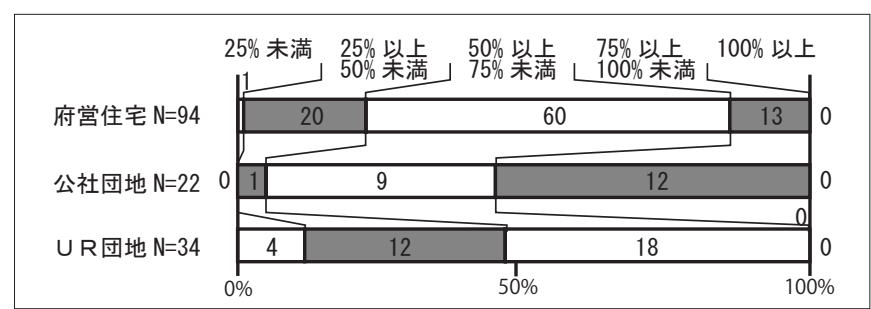

図 2 駐車場設置率 $(S 40$ 年代団地 $)$ 
表 2 市町村における設置基準

\begin{tabular}{|c|c|c|c|c|c|c|}
\hline \multicolumn{3}{|c|}{ 設置基準における条件分けの設定 } & 設置基準 & $\begin{array}{l}\text { 市町 } \\
\text { 村数 }\end{array}$ & $\begin{array}{c}\text { 団地数 } \\
\text { ※ }\end{array}$ & $\begin{array}{c}\text { 団地数 } \\
\text { ※ }\end{array}$ \\
\hline \multirow{4}{*}{\multicolumn{3}{|c|}{ 条件分け無し }} & $50 \% \cdot 50 \%$ 以上 & 8 & 27 & 4 \\
\hline & & & $70 \%$ 以上 & 1 & 7 & 2 \\
\hline & & & $80 \%$ 以上 & 1 & - & - \\
\hline & & & $100 \% \cdot 100 \%$ 以上 & 19 & 74 & 37 \\
\hline \multirow{16}{*}{$\begin{array}{l}\text { 条 } \\
\text { 件 } \\
\text { 分 } \\
\text { け } \\
\text { 有 } \\
\text { り }\end{array}$} & \multirow{4}{*}{ 戸数 } & 50戸以上 & $80 \%$ & 1 & 17 & 7 \\
\hline & & 51戸以上 & $70 \%$ & 1 & 13 & 3 \\
\hline & & 70戸以上 & $80 \%$ & 1 & 78 & 55 \\
\hline & & 201戸以上 & $100 \%$ & 1 & 13 & 7 \\
\hline & 開発面積 & $3000 \mathrm{~m}^{2}$ 以上 & $100 \%$ 以上 & 2 & 4 & 1 \\
\hline & \multirow{2}{*}{ 区分所有か否か } & \multirow{2}{*}{ 非区分所有 } & $50 \%$ 以上 & 1 & 2 & 1 \\
\hline & & & $70 \%$ 以上 & 1 & 3 & 2 \\
\hline & 住戸面積·戸数 & $35 \mathrm{~m}^{2}$ 超かつ70戸以上 & $50 \%$ & 1 & 68 & 11 \\
\hline & 開発面積·公的 & $3000 \mathrm{~m}^{2}$ 以上かつ公的住宅 & $70 \%$ 以上 & 1 & 26 & 10 \\
\hline & \multirow{2}{*}{ 地域·公的 } & 地域-a & $50 \%$ 以上 & \multirow{2}{*}{1} & 6 & 2 \\
\hline & & 地域-bかつ公的住宅 & $70 \%$ 以上 & & 12 & 6 \\
\hline & \multirow{5}{*}{ 用途地域 } & 第一種低層住居専用 & $80 \%$ 以上 & \multirow{5}{*}{1} & 1 & 1 \\
\hline & & 第一種中高層住居専用 & $60 \%$ 以上 & & 1 & - \\
\hline & & 第二種中高層住居専用 & $60 \%$ 以上 & & 1 & - \\
\hline & & 第一種住居 & $50 \%$ 以上 & & 1 & - \\
\hline & & 工業地域 & $80 \%$ 以上 & & 1 & 1 \\
\hline \multirow{3}{*}{ 他 } & \multicolumn{2}{|l|}{ 努力目標 } & $100 \%$ & 1 & 2 & - \\
\hline & \multicolumn{2}{|l|}{ 独自の基準無し } & - & 1 & - & - \\
\hline & \multicolumn{3}{|c|}{ 計 } & 43 & 357 & 150 \\
\hline
\end{tabular}

※「全対象団地」 ※※「s40 年代団地」

2)「S40 年代団地」( 図 2)

府営住宅における平均の設置率は 59.3\% であった。50\% 以上 $75 \%$ 未 満の団地が多かった。公社団地における平均の設置率は $75.9 \% 、 75 \%$ 以上 $100 \%$ 未満の団地が多かった。UR団地における平均の設置率は 48. $0 \%$ 、 $50 \%$ 以上 $75 \%$ 未満の団地が多かった。

(2) 市町村における設置基準 ( 表 2)

条例や指導要綱等に示された「世帯向け共同住宅における設置基 準注 5)」について、開発戸数に対する割合（\%)に換算した值を示した。 条件分けして規定している市町村については対象の団地が該当する 設置基準を示した。

43 市町村のうち、条件分けせず一律で設置基準を規定している市 町村が 29、条件分けして規定している市町村が 12 であった。条件分 けについてみると、「開発戸数」で分ける市町村が 4、「開発面積」「区 分所有住宅か否か」で分ける市町村がそれぞれ2、「住戸面積および 戸数」開発面積および公的住宅か否か」地域および公的住宅か否か」

「用途地域」で分ける市町村がそれぞれ 1 あった。

また努力目標としている市町村が 1、建築主事が置かず、独自の基 準を持たない市町村が 1 あった。

(3) 設置率と設置基準の比較

1)「全対象団地」

設置基準と設置率を比較すると（図 3)、設置基準が 50\%、50\%以 上に規定される区域にある団地で、設置基準を満たしていないのは、 府営住宅 49 団地中 24 団地 (49. $0 \%$ ) 、公社団地 2 団地中 1 団地 (50.0\%)、

UR団地 53 団地中 42 団地 (79.2\%) であった。

設置基準が 60\%、70\%、70\% 以上、80\%、80\% 以上に規定される区域 にある団地で、設置基準を満たしていないのは、府営住宅 79 団地中 71 団地 (89.9\%)、公社団地 26 団地中 10 団地 $(38.5 \%)$ 、U R 団地 55 団地中 47 団地 (85.5\%) であった。

設置基準が 100\%、100\% 以上に規定される区域にある団地で、設置 基準を満たしていないのは、府営住宅 66 団地、公社団地 10 団地、 UR団地 17 団地、全ての団地であった。

基準を満たしていない団地の設置率と設置基準の差 (単位ポイン

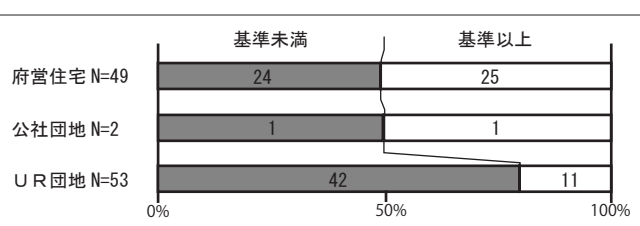

設置基準「50\%」「50\% 以上」の区域にある団地数

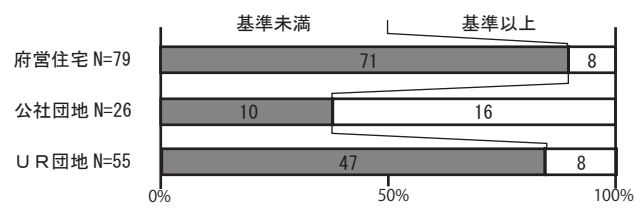

設置基準「60\%」「70\%」「70\% 以上」「80\%」「80\%以上」の区域にある団地数

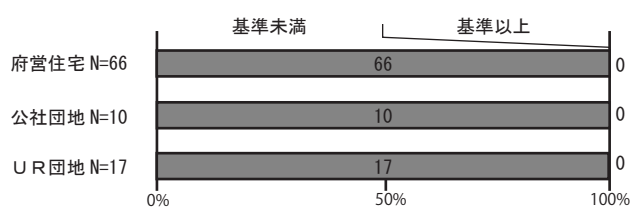

設置基準「100\%」「100\% 以上」の区域にある団地数

図 3 設置率と設置基準の比較 ( 全対象団地)

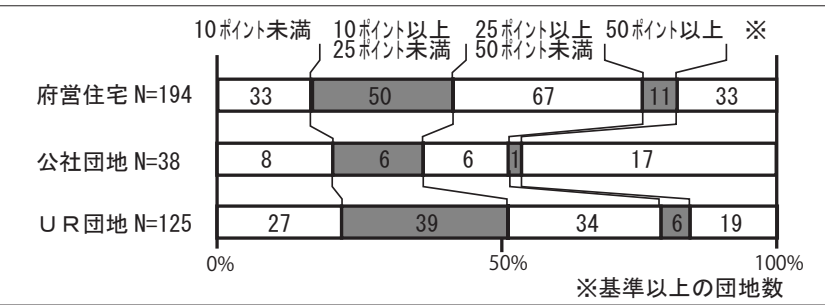

図 4 設置率と設置基準の差（全対象団地）

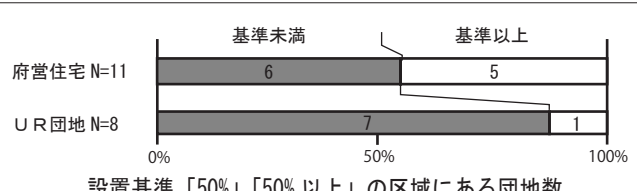

設置基準「50\%」50\% 以上」の区域にある団地数

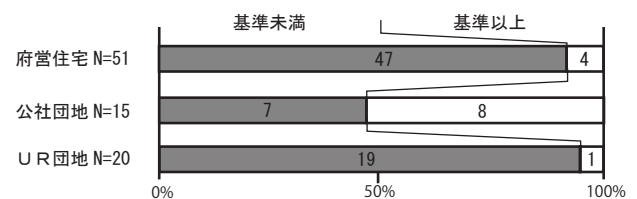

設置基準「60\%」「70\%」「70\% 以上」「80\%」「80\%以上」の区域にある団地数

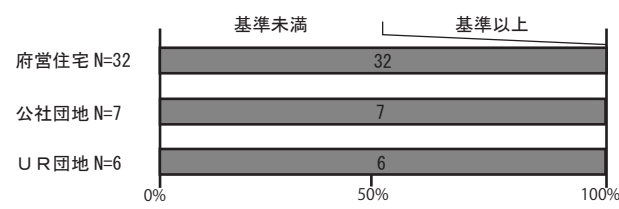

設置基準「100\%」「100\%以上」の区域にある団地数

図 5 設置基準と設置率の比較 (S40 年代団地)

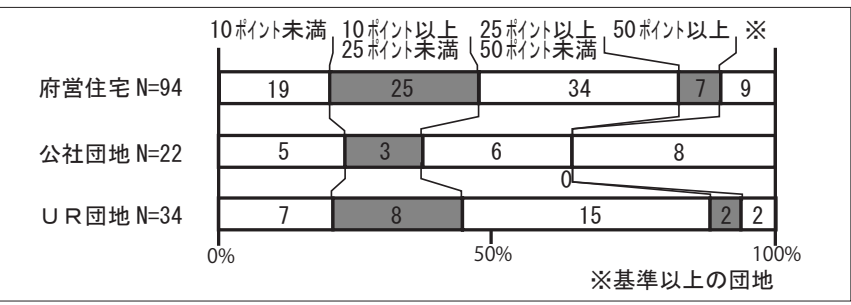

図 6 設置率と設置基準の差 (S40 年代団地) 
ト）をみると（図 4)、府営住宅では 25 ポイント以上 50 ポイント未 満の団地が多かった。公社団地では 10 ポイント未満、UR団地では 10 ポイント以上 25 ポイント未満の団地が多かった。

\section{2)「S40 年代団地」}

設置基準と設置率を比較すると（図 5)、設置基準が 50\%、50\%以 上に規定される区域にある団地で、設置基準を満たしていないのは、 府営住宅 11 団地中 6 団地 (54. 5\%)、U R 団地 8 団地中 7 団地 (87. 5\%) であった。公社団地はなかった。

設置基準が 60\%、70\%、70\% 以上、80\%、80\% 以上に規定される区域 にある団地で、設置基準を満たしていないのは、府営住宅 51 団地中 47 団地 (92. 2\%)、公社団地 15 団地中 7 団地 (46. 7\%)、UR団地 20 団 地中 19 団地 $(95.0 \%)$ であった。

設置基準が 100\%、100\% 以上に規定される区域ある団地で、設置基 準を満たしていないのは、府営住宅 32 団地、公社団地 7 団地、UR 団地 6 団地、全ての団地であった。

基準を満たしていない団地の設置率と設置基準の差についてみる と (図 6)、府営住宅、公社団地、UR団地とも、25 ポイント以上 50 ポイント未満の団地が多かった。

\section{3 設置基準を満たさない団地数}

設置基準を満たしていないのは「全対象団地」357 団地中 288 団 地 $(80.7 \%)$ であった。また「S40 年代団地」では 150 団地中 131 団地 (87.3\%) であった。「S40 年代団地」において、設置基準を満たして いない団地の割合は高かった。

設置基準を満たしていない「全対象団地」 288 団地について設置基 準から必要とされる台数を求めると 146,200 台であった。既設の駐 車場台数は 101, 515 台であり、44, 685 台が不足していた。また同じ く「S40 年代団地」131 団地において、設置基準から必要とされる台 数は 87, 204 台、既設の駐車場台数は 61,053 台であり、26, 151 台が 不足していた。

\section{3. 駐車場台数に余剩のある団地数}

\section{1 調査概要}

「S40 年代団地」において設置基準を満たしていない団地のうち「駐 車場台数に余剩のある団地数」を明らかにすることを目的として、 以下の調査を実施した。

府営住宅と公社団地については、各事業者から駐車場契約台数と 居住戸数について情報の提供を受け注 4)、これを整理した。UR団地 については、駐車場契約台数をU R 都市機構のウェブサイトに公開 された駐車場空き状況から整理し注 6)、居住戸数を現地調查の結果注 7) から整理した。これより各団地の保有率を求めた。駐車場設置台数、 管理戸数、保有率から需給差を求め、これが正值となる団地数を求 めた。

なお 131 団地のうち、募集を停止している団地を除いた 109 団地 (府営住宅 72 団地 48, 916 戸、公社団地 14 団地 5, 019 戸、U R 団地 23 団地 34,672 戸) を検討の対象とした。

\section{2 調査結果}

\section{（1）自家用車の保有率（図 7)}

府営住宅における平均の保有率は $47.1 \%$ であった。 $25 \%$ 以上 $50 \%$ 未 満の団地が多かった。公社団地と U R 団地における平均の保有率は、 それぞれ $56.5 \%$ 、 $42.3 \%$ であった。公社団地では $50 \%$ 以上 $75 \%$ 未満の

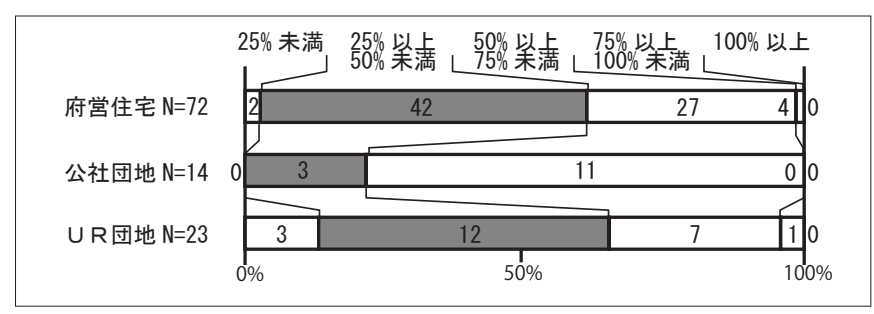

図 7 自家用車の保有率

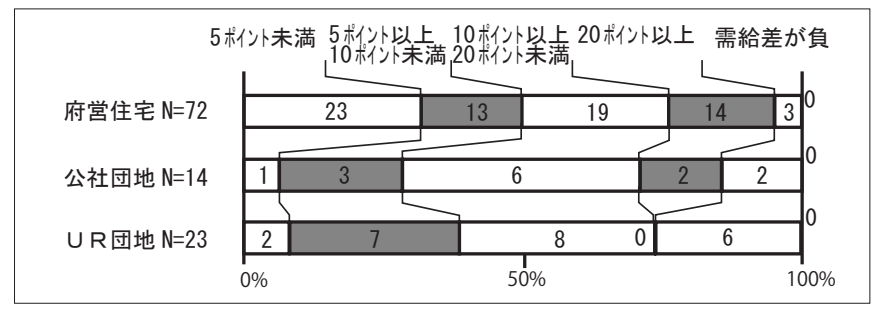

図 8 需給差

団地が多く、UR団地では $25 \%$ 以上 $50 \%$ 未満の団地が多かった。

(2) 需給差 (図 8)

需給差についてみると、府営住宅において需給差が正となる団地 は 72 団地中 69 団地 (95.8\%)であった。需給差が負となる団地は 3 団地であった。公社団地において需給差が正となる団地は 14 団地中 12 団地 (85.7\%)、UR団地では、23 団地中 17 団地 (73.9\%) であった。 需給差が負となる団地はそれぞれ 2 団地、6 団地であった。

\section{3 駐車場台数に余剩のある団地数}

需給差が正の団地を駐車場台数に余剩がある団地とすると、その 団地数は、対象とした 109 団地のうち 98 団地 (90.0\%)であった。こ の 98 団地における管理戸数は 72,781 戸、居住戸数 65,849 戸、設置 台数 42, 219 台、保有台数は 30,594 台であった。これより余剩台数 を求めると 8,376 台である注 8$)$ 。

\section{4. 団地の再生に対する駐車場設置指導の対応状況 4. 1 調査の概要}

団地の再生に対する駐車場設置指導の対応状況を明らかにするこ とを目的として、以下の調查を実施した。

大阪府下 43 市町村のうち建築主事のない 1 市町村を除く 42 市町

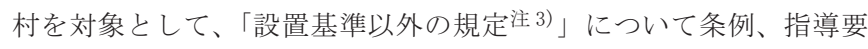
綱等を調查した。また同じく 42 市町村を対象としてアンケート調查 を実施し、「条例や指導要綱等に示されていない指導」の内容と、「公 的住宅 (市町村営住宅、府営住宅、公社団地、UR団地) の再生に おける設置基準の緩和事例」を調查した。アンケート調査では、ア ンケート票を、各市町村の開発指導の担当者に郵便、電子メールで 送付し、回答後に返信してもらった。調查は 2013 年 12 月に実施し、 42 市町村すべてから回答を得た。

これらの結果から、(1)設置基準以外の規定、指導の内容、(2)公的 住宅の再生における設置基準の緩和状況を整理し、(3)団地の再生に 対する駐車場設置指導の対応状況を検討した。

\section{2 調査結果}

\section{(1) 設置基準以外の規定、指導の内容}

\section{1）別途協議により駐車場台数を決定する開発（表 3)}

設置基準を適用しないで、「別途協議により駐車場台数を決定する」 
表 3 別途協議により駐車場台数を決定する開発

\begin{tabular}{|l|c|}
\hline \multicolumn{1}{|c|}{ 開発の内容 } & 市町村 \\
\hline 商業、近隣商業地域における開発の場合 & 3 \\
\hline 駅周辺における開発の場合 & 2 \\
\hline 進入禁止などの交通規制がある場合 & 2 \\
\hline 用途、敷地形状、規模、交通状況を勘案し支障がない場合 & 2 \\
\hline 駅周辺の商業地域、近隣商業地域の併用共同住宅の場合 & 1 \\
\hline
\end{tabular}

表 4 その他の規定、指導の内容

\begin{tabular}{|l|c|}
\hline \multicolumn{1}{|c|}{ 規定、指導の内容 } & 市町村 \\
\hline 開発区域外への設置の規定、指導 & 12 \\
\hline サービス付高齢者住宅における緩和の規定、指導 & 3 \\
\hline 高齢者専用共同住宅における適用除外の指導 & 1 \\
\hline 公的住宅における緩和の規定 & 1 \\
\hline 設置基準分の駐車場用地を確保した上で、当初の設置台数を減らす規定 & 1 \\
\hline
\end{tabular}

表 5 公的住宅の再生における設置基準の緩和事例

\begin{tabular}{|c|c|c|c|}
\hline 市町村 & 戸数 & 緩和内容 & $\begin{array}{l}\text { 緩和に当たっての状況 } \\
\end{array}$ \\
\hline TY 市 & 363 & $\begin{array}{l}\text { 設置基準 100\%に対し、 } \\
70 \% \text { を当初に整備して } \\
\text { 30\% の余剰地を確保する }\end{array}$ & $\begin{array}{l}\text { 戻り入居者の保有状況等を考慮し } \\
\text { 当初は } 70 \% \text { 、必要に応じて } 30 \% \text { 分の } \\
\text { 増設を行うとした。 }\end{array}$ \\
\hline M 市 & 364 & $\begin{array}{l}\text { 100\% の設置基準を 60\% } \\
\text { に緩和した }\end{array}$ & $\begin{array}{l}\text { 現状の駐車場設置状況及び利用状況 } \\
\text { や、域周の迢の極め駐車場におい } \\
\text { て不足分を確保する旨の内容を総合 } \\
\text { 的に判断して } 60 \% \text { に緩和した。 }\end{array}$ \\
\hline TI 市 & 284 & $\begin{array}{l}\text { 100\% の設置基準を 60\% } \\
\text { に緩和した }\end{array}$ & $\begin{array}{l}\text { 入居者の所得や必要時の確保に対す } \\
\text { る姿勢などを総合的に判断し、基準 } \\
\text { 必要台数の } 60 \% \text { を確保するとした。 }\end{array}$ \\
\hline
\end{tabular}

規定または指導がある市町村において、その対象とする開発につい て、条例、指導要綱等を調查した結果とアンケート調査の結果から 整理した。

「商業および近隣商業地域における開発」の場合に対象とする市町 村が 3 あった。「駅周辺における開発」、「進入禁止などの交通規制が ある開発」、「交通状況等を勘案し支障がない開発」の場合に対象と する市町村がそれぞれ 2 あった。「駅周辺、近隣商業地域における商 店との併用住宅の開発」の場合に対象とする市町村が 1 あった。

2）その他の規定、指導（表 4)

その他の規定、指導について条例、指導要綱等を調査した結果と、 アンケート調査の結果から整理した。

設置基準で示される駐車場台数の一部について、「開発区域外に用 地を取得して駐車場を設置する」ことを認める規定または指導があ る市町村が 12 あった。「サービス付高齢者住宅において設置基準を

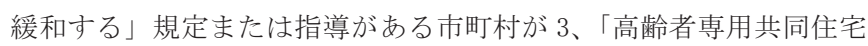
において設置基準を適用しない」とする指導がある市町村が 1 あった。

また「公的住宅において設置基準を緩和する」規定がある市町村 が 1 あった。「設置基準分の駐車場用地を確保した上で、当初の設置 台数を減らす」ことを認める規定がある市町村が 1 あった。

（2）公的住宅の再生における設置基準の緩和状況（表 5)

公的住宅の再生における設置基準の緩和状況についてアンケート 調査結果から整理した。

TY 市における事例は、建替え事業 (363戸) において、戻り入居 世帯の自家用車保有状況を勘案し、設置基準 100\%に対して、当初に $70 \%$ 分を整備し、残り $30 \%$ 分は用地を確保したうえで必要に応じて増 設するという指導を行った事例であった。M市の事例は、建替え事業 (364戸) において、事業前の駐車場設置および利用状況を勘案し、 設置基準 100\% に対して 60\%に緩和した事例であった。TI 市における
事例は、建替え事業 (284戸) において、入居者の所得などを勘案し、 設置基準 100\% に対して 60\% に緩和した事例であった。

\section{3 団地の再生に対する駐車場設置指導の対応状況}

団地の再生を、「別途協議により駐車場台数を決定する」開発とす る市町村は無かった。また「その他の規定、指導」においても団地 の再生は位置づけられていなかった。

一方、公的住宅の再生において設置基準を緩和する指導はあった。 それらの指導では、再生前の駐車場設置状況、使用状況、戻り入居 世帯の自家用車保有状況などに基づいて設置基準が緩和されていた。 また緩和の内容として、「設置基準を緩和する」「設置基準を満たす 駐車場用地を確保したうえで、当面の設置台数を減らす」の 2 つが 挙げられた。

これより、団地の再生に対する駐車場設置指導の対応状況につい てみると、市町村の条例、指導要綱等において、団地の再生は直接 的には位置づけられていない注 9)こと、団地の再生において設置基 準を緩和する指導を行った市町村があることが分かった。

\section{5. 考察}

\section{1 団地の再生における駐車場設置指導の課題}

本稿では以下の 3 点が明らかとなった。築 50 年を迎えることで、 再生の必要性が高まる「S40 年代団地」では、(1)調査対象とした 150 団地中 131 団地が駐車場の設置基準を満たしていなかった。(2)その内、 98 団地において駐車場台数に余剰があった。(3)団地の再生において、 設置基準を緩和する駐車場設置指導が行われた事例はあるが、現状 の駐車場設置に係る条例、指導要綱等において、団地の再生は位置 づけられていなかった。

よって今後の団地の再生において、「余剩があるにもかかわらず、 市町村の指導により駐車場が増設され、使われない駐車場という無 駄な空間を生む可能性のある団地」は多い。

これより、団地の再生における駐車場設置指導の課題は、設置基 準を満たさず駐車場に余剰のある団地の再生において、無駄な駐車 場を生まない条例、指導要綱等の体系をつくることである。

\section{2 団地の再生における駐車場設置指導のあり方}

課題を踏まえ、今後の団地の再生における駐車場設置指導のあり 方は、以下の 3 点であると考えられる。

(1)団地の再生では、駐車場の設置率を、再生前の駐車場利用状況、 戻り入居世帯の自家用車保有状況を踏まえ、再生に伴い新たに入居 する世帯の自家用車保有状況、将来の居住世帯の入れ替わりによる 需要の変化を見込み、必要な分を確保する設置率とし、無䭾な駐車 場を生まない指導とすること。

(2)再生に伴い新たに入居する世帯の需要や、将来の居住世帯の入れ 替わりによる需要の変化を吸収する余裕を見込むが、「用地を確保し たうえで必要に応じて整備する」段階的整備を認め、再生当初にお いて、無駄な駐車場を生まない指導とすること。また、用地は緑地、 広場、仮設による施設整備等、他の目的による利活用を可能にしつつ、 駐車場に転用することを可能にする配置、勾配、平面形状とする指 導とすること。さらに、使用されなくなった駐車場を、団地の状況 に応じた転用を可能とする指導とすること。

(3)上記(1)(2)の指導を明確化するために、団地の再生を「設置基準に おける条件分けの一つ」として規定したり、「別途協議により駐車場 
台数を決定する開発内容」に指定するなど、条例や指導要綱等に、 団地の再生を位置づけること。

\section{3 今後の課題}

本論において対象としなかった「設置率が設置基準を満たしてい ない分譲住宅団地や民間マンション」の再生においても無䭾な駐車 場が発生する可能性がある。分譲団地、民間マンションの自家用車 保有状況を把握し、駐車場設置指導のあり方について検討する必要 がある。

\section{謝辞}

資料を提供いただいた大阪府、大阪府住宅供給公社、U R 都市再 生機構、アンケート調查にご協力いただいた市町村に感謝いたしま 寸。本研究は、「文部科学省私立大学戦略的研究基盤形成支援事業 (平 成 23 年度〜平成 27 年度)」の一部として実施されたものである。

注

注 1) 府営住宅のうち、入居者の収入基準が異なる特定公共賃貸住宅、さらに 府営住宅と公社団地が混在するペア住宅を除外した。

注 2) 事例を示寸。管理戸数 1, 428 戸、駐車場設置台数 734 台（設置率 $51.4 \%(734$ 台 $/ 1,428$ 戸)）の団地において入居戸数は 1,252 戸、保有台数は 487 台 (保 有率 $38.9 \%$ (487 台/ 1,252 戸 )) であった。空き駐車場台数の実数「駐車 場設置台数一保有台数」は 247 台 $(734$ 台一 487 台) であるが、これには 空き住戸 176 戸 $(1,428$ 戸- 1,252 戸、空き家率 $12.3 \%)$ に入居する世帯 が必要とする台数が含まれる。そこで、空き住戸に入居する世帯が保有 寸ると想定される台数を 68 台 ( 空住戸数 $\times$ 保有率 $=176$ 戸 $\times 38.9 \%)$ と し、この分が過大に評価されているとした。これより想定される台数 68 台に、保有台数を加えた 555 台 $(68$ 台 +487 台) を必要駐車場台数と寸 ると、余剩台数「駐車場設置台数一必要駐車場台数」は 179 台 $(734$ 台一 555 台）、需給差「余剩台数/管理戸数」は 12.5 ポイント $(179$ 台 / 1,428 戸) となる。な拉、必要駐車場台数 555 台は、「管理戸数 $\times$ 保有率 $=1,428$ 戸× $38.9 \% 」 に よ り$ 求められ、需給差 12.5 ポイントは「設置率一保有率 $=51.4 \%-38.9 \%$ によって求められる。

注 3) 事例を示す。管理戸数 340 戸、駐車場設置台数 220 台の団地におい て、入居戸数は 304 戸、保有台数は 203 台であった。この場合、保有率 は $66.8 \%$ (203 台／304 戸) となり、必要駐車場台数は 227 台 (340戸× $66.8 \%)$ である。必要台数が駐車場設置台数を上回り、余剩台数は -7 台 $(220-227$ 台)、需給差は、- 2.1 ポイントとなることから、本論では 余剩がないと定義した。ただし、203 台を収容する駐車場は確保されてお り、本団地の現状においては駐車場台数の不足にはなっていない。この ような場合、具体的にどこに不足が生じるかといえば、空き住戸の多く に入居があり、それら世帯の保有率が、既居住世帯の保有率と同率であっ た場合に、駐車場台数の不足が生じる。

注 4) 2013 年 3 月末時点において

注 5) 2015 年 4 月時点において

注 6) ウェブサイトの調查を 2015 年 2 月に実施した。ウェブサイトで公開され た各団地別の空き駐車場台数を、団地の駐車場設置台数から差し引き、 契約台数とした。

注 7) 調查は 2015 年 2 月に実施した。各団地の空き住戸数を目視により確認し、 管理戸数から差し引き、居住戸数とした。

注 8) 以下の計算による。保有率は $46.5 \%(30,594 / 65,849)$ 、必要駐車場台数は 33,843 台 $(72,781 \times 46.5 \%)$ 、余剩台数は 8,376 台 $(42,219$-33, 843) である。

注 9) 設置基淮において公的住宅を条件分けし、他の開発より低い設置基淮と している2市町村 (表 2)、その他の規定において公的住宅を緩和の対象 としている1市町村は、公的住宅における自家用車保有率が低いことを 考慮した設置基準、規定であり、間接的に団地の再生に対応しているが、 ここでは条例、指導要網等に「建替え事業の場合」などと、直接的に対 応していないことを述べた。

\section{参考文献}

1) 北原啓司, 近江隆 : 公営住宅団地における駐車場実態と整備課題, 日本建 築学会東北支部研究発表会, pp107-112, 1991. 6

2）田中勝：公営住宅居住者の自動車保有実態と駐車場整備要求：名古屋市営
住宅 6 団地の調査・分析 (建築経済・住宅問題), 日本建築学会学術講演梗 概集 , F, pp707-708, 1991.9

3）関原明, 星野輝雄 : 公団新規建設住宅の車庫問題とその対策, 都市計画 171, pp66-69, 日本都市計画学会, 1991.9

4）福岡研悟, 野口孝博, 眞嶋二郎, 森下満 : 集合住宅における居住者の自動車 利用特性と駐車場・オープンスペースの形態 - 札幌市内の都心、周辺、郊外 地区の集合住宅事例の分析 -, 日本建築学会北海道支部研究報告集, pp $341-$ 344, 1998.3

5）南尣坤, 宇佐美諒, 杉山茂一, 徳尾野徹：既成市街地に立地する集合住宅に おける駐車空間の採り方, 日本建築学会計画系論文集, 614, pp17-24, 2007. 4

6) 賀満田将悟, 柴田祐, 澤木昌典：千里ニュータウン新規入居者の車所有の 実態と駐車場碓保に関する研究, 日本都市計画学会関西支部研究発表会講 演概要集, vol.11, pp113-116, 2013.7 


\title{
ISSUES OF PARKING INSTALLATION GUIDANCE IN THE REDEVELOPMENT OF PUBLIC RENTAL HOUSING COMPLEX
}

\author{
Takashi YASUMOCHI* ${ }^{*}$ Yuka KATAOKA **, Tohru KURACHI*** \\ and Naoki EGAWA**** \\ * Doctoral Course, Graduate School of Engineering, Kansai University \\ ** Research associate, Center for Disaster Management informatics Research, Ehime University, Dr.Eng. \\ *** Research Fellow, Kansai University, Dr.Eng. \\ **** Prof., Kansai University, M.Eng.
}

Parking lots in public rental housing complex (PRHC) have been added. However there is still the PRHC that doesn't meet the installation criteria municipality stipulated. On the other hand, in some PRHC there is a surplus in the parking lots. When the municipality applied the criteria of the current situation to redevelopment of the PRHC that doesn't meet the criteria despite the surplus of parking lot, the wasted space would be generated. The purpose of this study is as follows. 1. To reveal the number of PRHC that parking installation rate doesn't meet the criteria, 2. To reveal the number of PRHC with a surplus in the parking lots, 3 . To reveal the guideline situation of municipalities in redevelopment, 4 . To present the issues and desirable future direction of leadership of municipalities.

The following investigations were subjected on the PRHC in Osaka prefecture.

A number of current parking lots in the PRHC and installation criteria municipality stipulated have been investigated. Based on the results the installation rate and criteria were compared. The residence number of households owned private cars have been investigated. Based on the results the ownership rate and installation rate were compared. On the other hand, a questionnaire survey of the development guidance was conducted to the municipality of Osaka Prefecture. Based on these results, the issues and the direction of the guideline in the future of redevelopment were considered.

Results of the investigation, the following became clear. The PRHC which doesn't meet the installation criteria are 288 PRHC of 357 (80.7\%). A parking number 146,200 units required based on the installation criteria. The current status of the installed parking number is 101,515 units. 44,685 units in these PRHC are missing. In the PRHC that was built in 1965-1974, the PRHC that doesn't meet the installation criteria are $131 \mathrm{PRHC}$ of 150(87.3\%). A parking number 87,204 units required based on the installation criteria. The current status of the installed parking number is 61,053 units. 26,151 units in these PRHC are missing. There was a surplus in the 98 PRHC of the 109 PRHC (from 150 PRHC except for the recruiting stop). Current status of the installed parking number is 42,219 units. In these PRHC the surplus of the parking number is 8,376 units.

On the other hand, the results of the questionnaire survey, there was no municipality having a reference intended for the redevelopment of the PRHC directly. However, in the redevelopment, cases relaxed the installation standards was present in 3 municipalities. Judgment based on the previous redevelopment situation had eased the installation criteria, such as possession situation of private cars in returning households, parking installation conditions and usage status. There are the following two methods as a way to relax. 1. Immediate installation number is reduced. It is however a condition to secure the site that meets the criteria installation in the future. 2. Reducing the installation rate.

Conclusions are as follows. Issues of the future of guidance are a revision of installation criteria at the time of redevelopment of the PRHC that doesn't meet the installation criteria. Direction of guidance in the future of the redevelopment is as follows. 1. Current guidance must be revised to the guidance that doesn't generate a useless parking space, by provide guidance based on the private car owned situation of resident households and previous parking installation situation. 2. To provide guidance of a step-by-step construction of necessary, in order to not generate wasted space at the beginning of the redevelopment. 3. To include the provisions related to redevelopment in the regulations and guidelines. 